\title{
Maailma esimesed inimesed - Valgevene ja Eesti etioloogiad
}

\author{
Alena Boganeva \\ Valgevene Rahvusliku Teaduste Akadeemia \\ Kultuuri, Keele ja Kirjanduse Uurimise Instituudi \\ etnolingvistika ja folkloristika sektori juhataja \\ elboganeva@gmail.com
}

Mare Kõiva

Eesti Kirjandusmuuseumi folkloristika osakonna juhtivteadur mare.koiva@folklore.ee

\begin{abstract}
Teesid: Valgevene ja Eesti müütilistes narratiivides, eriti etioloogiates, on palju sarnaseid motiive ja tegelasi, hoolimata sellest, et eestlased ja valgevenelased kuuluvad erinevatesse keelkondadesse ja nende asualal pole ühiseid piire. Kokkulangevused motiivides on seejuures sedavõrd täielikud ja väljendusrikkad, sh maailma esimeste inimestega seotud etioloogiates, et meile näib, et neid on raske tüpoloogia või universaalidega selgitada.

Kuna Eesti ja Valgevene rahvaluule seoseid ei ole peaaegu uuritud ${ }^{1}$ (nagu ka nende kahe rahva ajaloolisi kontakte), on meie artikli siht osutada valitud näidete põhjal sarnasustele Eesti ja Valgevene motiivides käepäraste slaavi ja soome-ugri paralleelide kontekstis ning tutvustada etioloogiaid küüntest naha, inimeste korduva loomise, naise loomise jm etioloogiate näitel.
\end{abstract}

Märksõnad: Aadam, Eeva, etioloogia, parapiibel, piiblimõjuline folkloor

Etioloogiad jutustavad maailma loomisest ja hukust, erinevate olendite, inimese ja loomaliikide, rituaalide, riikide, keelte jm tekkimisest. Neid jutustati muistendi- ja muinasjutuvormis või esitati eepiliste lauludena. Folkloristikas määratletakse neid seletus- ja tekkelugude kategooriasse, millest osa on lähedased piiblile ja mõjutatud laiemast piiblikirjanduse, sh apogrüüfide kogumist. Etioloogiliste legendide stiilivahemik ulatub tõsistest jutustustest humoristlike ja jämekoomiliste päritolulugudeni, kõrgstiilist tavakeele allstiilideni (vrd Belova \& Kabakova 2014: 9), nende juurde kuuluvad esitajate arutlused, didaktilised, moraalikoodeksile osutavad üldistused ja kooda - lugu, jutustust lõpetav osa.

Piiblifolkloori uurimine ulatub 19. sajandisse, kuid tähtsamad klassifikatsioonid ja liigikirjeldused pärinevad 20. sajandist. Hermann Gunkeli (1987 [1917]) märgiline uurimus "Muinasjutud Vanas Testamendis" (Das Märchen im Alten Testament) tõi esile piiblis kirjeldatud aladel elanud rahvaste folkloori ja 
piibli ühisjooni. Folkloori pidas Gunkel pühakirja mõjutajaks, mille tõttu sisaldab pühakiri Euroopa ja Aasia rahvastele omaseid teemasid ja sisuelemente. Piiblis leiduva folklooriga tegeles tohutu koondatud ainestiku põhjal ka antropoloog ja usundi-uurija James Frazer (1918), kelle teos "Folkloor vanas Testamendis" (Folk-lore in Old Testament) kujunes tähtsaks allikaks ka hilisematele õpetlastele. Piiblis leidub erinevaid folklooriliike: hümnid, palved, loitsud ja rituaalid, itkud ja armastusluule, eepika, muistendid, müüdid ja genealoogiad, historiograafilised tekstid, rahvapärased normid ja käsud - loetelu ei ole ammendav ja kõik liigid ei ole saanud ka võrdses mahus tähelepanu. 20. sajandi alguse käsitlused leidsid 1960. aastatel jätkamist. Euroopa ja Põhja-Ameerika folkloriste huvitasid rohkem üldteoreetilised küsimused ja narratiivsed vormid, mõistetavalt on ainestiku käsitlemisel olnud tegevad peale folkloristide ka teiste erialade õpetlased: antropoloogid, kirjandusteadlased, lingvistid ja filosoofid. ${ }^{2}$ Vana ja Uue Testamendi folkloori peajooni analüüsinud folkloristide kirjatööd olid olulisel kohal ka käesoleva artikli teoreetilise aluse loomisel (vt Alan Dundes (1999); Dan Ben-Amos (2009 [1972]); Galit Hasan-Rokem (1990); lingvist Dell Hymes; Patricia E. Kirkpatrick (1988); James Rogers (2010 [1884]); aga ka Susan Niditch (2018)).

1990. aastatest alates on etioloogiad olnud fookusteema ka Ida- ja KeskEuroopa folkloristikas (nt Nagy 1990; Belova \& Kabakova 2014; Badalanova Geller 2008, 2011, 2017; Boganeva 2010). Nende autorite käsitlused ja kommenteeritud tekstivalimikud olid abiks mõlema rahva paralleelide leidmisel. ${ }^{3}$

Arutlustihe on olnud piibli kirjakohtade vahekord muinasjuttude ja muistenditega, samuti müütide, muistendite ja (kristlike) legendide vormikirevus piibli-aladel (Sparks 2005; Hoffmeier \& Wenham \& Sparks 2015), esimeste inimeste etioloogiate variaablus kerkib esile ka meie materjali hulgast. Dan Ben-Amose (2009: 134) formuleering sedastab: "Žanridel on normatiivne võime, mille abil nad piiritlevad antud vormile ja koosesinemiseks sobivad selged teemad, struktuurid ja stiilid. Ka on neil eristav võime. Žanride lähemad tunnused märgivad piire folkloorsete väljenduste tõlgendamise vahel, määrates uskumise, huumori või meelelahutuse suhte jutustatud või lauldud teatesse." Siiski loobusime žanrikategooria järgimisest, sest võime oma materjalis näha sujuvaid üleminekuid jutuliikide vahel ja olukordasid, kus uskumise ega huumori vahel pole võimalik vahet teha.

Etioloogiad on tüübi tasandil korrastatud rahvajutukataloogidesse alates Oskar Dänhardti "Loodusmuistendite" I-IV kogumikest (1907-1917) Antti Aarne soome (1912) ja eesti (1918), Oskar Looritsa (1926a) liivi jutukataloogini. Vaatamata 1963. aastal Rahvusvahelise Rahvajuttude Uurimise Seltsi erikomisjoni otsusele (Tagung 1964) alustada etniliste muistendikataloogide 
koostamist, on muistendite ja etioloogiate erikataloogide valmimine viibinud materjali keerukuse ja teisalt allikate vähese läbitöötamise tõttu.

Viimastesse kümnenditesse kuulub uus lähenemine, mis vaatleb piiblil ja piiblikirjandusel põhinevat jutustamist omalaadse ala- või vaheliigina, millel on suulise ja kirjaliku narratiivsuse tunnuseid. Esialgu ei ole suudetud uut alaliiki rahuldavalt piiritleda ja terminitega katta, liigikirjeldusi on vähe ja ka tekstide fikseeringuid pole palju. Üldmääratlustes on viidatud, et need tekstid on osa vernakulaarsest piiblist ja tegemist on folkloori ja piiblikirjanduse ühise piirialaga, kus jutustatakse üsna täpselt ümber piiblisündmusi ja kirjakohtasid. Nagu tõdeb Florentina Badalanova Geller (2017) ei peetud tekste tihti üleskirjutamise vääriliseks ja see üldistus kehtib täiel määral ka mõlema rahva varasema traditsiooni kohta. Meie vaatlusalused alad kujutavad endast ka huvitavat piiri õigeusu, protestantismi ja katoliikluse vahel ning mõlema rahva juures levis suurem osa motiive ja usundilisi narratiive kõigis kogukondades vähemalt vernakulaarse suhtlemise tasandil.

\section{Andmed etioloogiliste kogude kohta Eestis ja Valgevenes}

Meie käsitletavad etioloogiad piirduvad 19. kuni 21. sajandi üleskirjutustega ja vaatlevad ühe temaatilise rühma valitud motiive. Piiblil põhinevad rahvapärased etioloogiad esindavad mõlemal rahval muinasjutužanriga võrreldes väiksemat ja vähem uuritud tekstikorpust.

Maailma loomise ja esimeste inimeste teema on esindatud Oskar Looritsa "Liivi rahva usundi" I-III köites (1926-1928) ja IV-V köites (2000) (vt Loorits 1926b: 126; 1928: 181; 2000: 144, 146, 151-152), aga Eesti tekste leidub hilisemas teoses "Eesti rahvausundi peajooned" (Grundzüge des estnischen Volksglaubens, 1949-1951). Tähtsamad jutumotiivid on loetletud Antti Aarne "Eesti muinasjuttude ja muistendite kataloogis" (Estnische Märchen- und Sagenvarianten, FFC 25, Aarne 1918: 139-153, AaS 10-264) ja Oskar Looritsa koostatud "Liivi muinasjuttude ja muistendite kataloogis" (Livische Märchen und Sagenvarianten, FF C 66, Loorits 1926a).

Eesti folkloristid on põhjalikumalt tegelenud lühivormidega, vaadeldud on nt Piibli-vanasõnade ja ütluste levikut, mõistatusi ja loitse (nt Krikmann 1999; Kõiva 2020). Arvo Krikmanni (1986) ärgitas teoreetiline küsimus autentsusest ja kopeerimisest ning piiblitõlgete mõjust kohalikule vanasõnade korpusele. Tema arvates olid piiblile sarnanevad tekstid tingimata laenud trükisest, muud levimisvormid jäid tagaplaanile. Veel varasemasse aega kuuluvad Oskar 
Looritsa tähelepanekud piiblisündmuste ja -tegelastega seotud temaatiliste mõistatuste esinemusest eesti folklooris (Loorits 1935).

Eesti Kirjandusmuuseumi rahvaluule arhiivi kartoteegi tekstiviiteid ja muid otsinguid aluseks võttes on sisestatud käsikirjadest üle tuhande lehekülje etioloogiaid. 227 teksti käesoleva valimi jaoks saadi Skriptooriumist (digitaalne arhiiv ja ressurss folkloristika osakonna digiteeringute töötlemiseks, valdavat enamikku etioloogiatest ei ole trükistes avaldatud). Nendes tekstides eristuvad selgelt esimeste inimeste loomise teemad, Aadama ja Eeva elu Eedeni aias enne ja pärast pattulangemist (selle kohta vt allpool). Jutustuste juurde kuuluvad kommentaarid on eraldi uurimisteema ja jäetud suuremas osas kõrvale.

19. sajandi lõpus ja 20. sajandi alguses viidi Valgevene territooriumil ja selle piirialadel läbi mitmeid uuringuid, mille tulemusena ilmusid fundamentaalsed rahvaluuletekstide kogumikud, sealhulgas rahvaproosa teosed, milles nii piibellike kui rahvapäraste etioloogiliste legendide osa on märkimisväärne (Dobrovolski 1891; Romanov 1891; Shein 1893; Federowski 1897; Seržputovski 1911, 1930; Pietkiewicz 1938 jne). Nõukogude ajal, alates 1930. aastatest olid legendid (aga ka usundilised narratiivid ja mis tahes muud usundi ja üleloomulikkusega seotud žanrid, sh imemuinasjutud, lood imetegudest, lood jumala abist ja karistusest) kogu idaslaavi aladel ja ka "sotsialismileeri" riikides religioossuse tõttu uurimishuvide äärealadel. Siiski on Valgevenes 20. sajandi lõpust tänapäevani läbi viidud sihipäraseid väliuuringuid, mille tulemusena on kogutud ulatuslik legendiliste ja mütoloogiliste narratiivide kogu. Valgevene tänapäevased rahvaluulematerjalid, sealhulgas legendid esimestest inimestest, leidsid kajastamist sellistes väljaannetes nagu "Legendid ja pärimused" (Grinblat \& Gurski 1983; 2005), "Valgevene rahvapiibel tänapäevastes ülestähendustes” (Boganeva 2010), suulisele Piiblile ja etioloogilistele legendidele pühendatud peatükid kümneköitelises sarjas "Valgevenelaste traditsiooniline kunstiline kultuur" (TMKB 2004: 719-724, 752-761; 2006 (2): 348-399; 2009 (2): 373-439; 2011 (2): 384-454; 2013 (2): 526-611), "Polotski etnograafiline kogumik" (Lobach 2011 (1): 25-26) jt. Valgevene folkloori- ja etnolingvistilise atlase $^{5}$ elektroonilises andmebaasis on 3580 müütilist ja usundilist narratiivi, millest 163 teksti on legendid esimestest inimestest. Käesoleva artikli jaoks kasutasime kõiki erinevate perioodide käsikirjasid, digiteeringuid ja trükiseid. 


\section{Etioloogiate tajumine traditsioonikandjate poolt - kas tõde või väljamõeldis}

Jutustajad ja kirjasaatjad määratlevad suulisi piibliteemalisi tekste ja süžeesid kui endisaegse elu kirjeldusi, viidates samaaegselt suulisele traditsioonile ja kirjalikule allikale - Piiblile ja Jumala seadusele. Näiteks rahvaluulekoguja küsimusele, kes on Aadam ja Eeva, vastas valgevene informant:

Адал, па Бібліі пішациа, свяшчэннік. А Ева - Міколь Чудатвориа saui

Piibli järgi on Aadam preester. Ja Eva on Mikola Imetegija ema (Boganeva 2010: 32).

Nagu näitavad aastatel 1995-2019 tehtud tänapäevased uuringud, võivad Valgevene traditsiooni kandjad nimetada etioloogiaid "pajatus", "tähendamissõnad", "muinasjutt" või "kõnekäänd”, andmata neile nimetustele mingit täpset žanrimääratlust. Kuid isegi etioloogilisi legende muinasjuttudeks või pajatusteks nimetades arvavad informandid kõige sagedamini, et neis kirjeldatakse tõestijuhtunud sündmusi, mis toimusid mingil ebamäärasel kaugel ajal. Näiteks tänapäeval haruldase sugude erinevuste põhjustest kõneleva jutu etioloogilise versiooni alguses kinnitab informant kohe:

See, lapsuke, on tõsi. See on tõsi. Nii algas valgus, laps, see on tõsi. See pole muinasjutt, ei. See on tõsi, kullake, nii see kõik on. ${ }^{6}$ (TMKB 2011: 389-390).

Selline kinnitus ei hooli asjaolust, et etioloogiatel sooliste erinevuste kohta on peaaegu alati humoristlik alatoon. See tähendab, et etioloogilistel legendidel on tänapäevaste informantide tajus kahetine staatus: ühest küljest ei suhtuta neisse nüüd enam täie tõsidusega. Need on teosed, mis on aksioloogiliselt "madalamad", võrreldes näiteks pühakirjaga (kuigi need suulises käibes sageli omavahel segunevad), teisest küljest on need traditsiooni kaudu legitimeeritud tekstid, mis selgitavad maailma nähtusi, manitsevad, ja on seega jutuvestjate jaoks hädavajalikud.

Eesti etioloogiaid pandi aktiivselt kirja 19. sajandi algusest 20. sajandi 40. aastateni ja tänapäeval on need valdavalt hoiul rahvaluule arhiivi kogudes. Arhiivikirjetes jutustaja suhtumine loo tõesusse üldjuhul ei kajastu, kuid isegi kui etioloogial on humoorikas kõla, on sellel eelkõige selgitav kavatsus, millest annavad tunnistust ühtede ja samade süžeede kirjapanekud erinevatelt jutuvestjatelt Eesti erinevates piirkondades. ${ }^{7}$ 


\section{Mõned sagedasemad motiivid esimestest inimestest Eesti ja Valgevene traditsioonides}

Süžeed esimestest inimestest, nende pattulangemisest ja selle tagajärgedest on üks populaarsemaid ja kõige eriplaanilisemaid Eesti ja Valgevene vernakulaarseid piiblilugusid. Aadama ja Eeva nimega seotud süžeedes on paljudel Euroopa rahvastel (aga ka juutidel) kolm üksteisele järgnevat osa, mis Piibli originaalist oluliselt erinevad: 1) süžeed esimeste inimeste loomisest; 2) süžeed pattulangemisest ja nii esimeste inimeste olemuse kui ka maailmakorra muutumisest; 3) süžeed, mis kõnelevad Aadama ja Eeva elust pärast paradiisist väljakihutamist (selle kohta vt Kaspina 2000). Igas konkreetses tekstis võivad need osad nii üksteisele järgneda, moodustades ühtse jutustuse, aga võivad ka eksisteerida paralleelselt ja üksteisest sõltumatult.

Artikli piiratud mahu tõttu võtame arvesse ainult valitud eesti ja valgevene motiive, mis kuuluvad esimeste inimeste süžee neisse kolme ossa ja pöörame tähelepanu peaasjalikult paralleelidele meie traditsioonides. ${ }^{8}$

Esimeste inimeste loomise teema Eesti ja Valgevene rahvalikes piiblinarratiivides on esitatud Piibli originaalile lähedaste ümberjutustustena, aga ka folkloorsete tekstidena, millel peale teema ja tegelaste peaaegu puudub seos Piibliga. Eesti ja Valgevene legendides kohtab inimeste loomise kohta dualistlikke motiive, kus kurat osaleb inimeste loomises. Nende tekstide sisu on Piiblist kaugel ja sellised dualistlike motiividega tekstid on levinud kogu maailmas (vt StTh-MIFL A2; Berezkin B 01; ATU 773) $)^{9}$.

\section{Tekstid kahest loojast}

Petserimaalt pärit tekst inimese loomise kohta kajastab ettekujutust kahest loojast.

Ku' Jummal inemise tekk valmist ar', syss tä pand tuu sauõtsõ kujo kuioma. Esi läts hinge perrä. Pand huss mano vahi pääle. Halv tiiäi midä hussilõ lubasi, nigu huss lask ar mano. Sülel' inemise ar' nigu ei teeägi. Tull Jummal mano, pühk, pühk, õks jõua-as kyikõ ar' pühki. Kandlitsoppõ jäi veel tuud sülge. Muido mi olnu ka’ nii puhta nigu elläi. Olnu-us kuurõivit es midägi (ERA II 194, 475 (11) < Setu, Petseri v, Risjova k - Ello Kirss < Tat'o Kallaste, snd 1875 (1938)).

Teises loos avab koer värava paradiisiaeda, kurat siseneb ja koer lubab inimestel süüa keelatud puu vilju. 
Valgevenelastel leidub sarnaseid legende 19. sajandi lõpu kirjapanekutes. Jumal loob inimese ja lahkub, pannes teda valvama koera, kes esialgses variandis oli karvutu ja kartis külma. Kurat laseb koeral külmetada, puhub tema suunas külma õhku ja lubab anda talle kasuka vastutasuks vaba pääsu eest inimese juurde. Koer laseb kuradi sisse ja too sülitab inimese peale. Kui Jumal tagasi tuleb, soovitab kurat tal inimese pahupidi pöörata, et kõik räpane ja sellega koos ka haigused sissepoole jääksid. Jumal teebki nii (Dobrovolski 1891: 230-231). ${ }^{10}$ Valgevenelaste igapäevases käibes seda legendi enam ei kohta, kuna dualistlike motiividega tekstid ongi tänapäeval üliharuldased.

Inimese loomise etioloogiates on analoogseid motiive (saatan sülitab inimese peale, kuradi süljepritsmetest tekivad haigused, Jumal pöörab inimese pahupidi) ka venelastel (Belova \& Kabakova 2014: 228, nr 354; VESiL 2019: 15-16), ukrainlastel (Bulašev 1992: 91-92, 104; Dragomanov 1876: 1, nr 1) ja bulgaarlastel (Badalanova Geller 2017: 338-341, nr 138). Taolisi motiive leiab slaavi apokrüüfist "Kuidas Jumal lõi Aadama" (Põpin 1862: 12-13). ${ }^{11}$ Ainult et nimetatud apokrüüfis ei sülita kurat inimese peale, vaid togib teda kaugelt kepiga, kuna koer ei lase kuradit inimese juurde. Sellest tulenevalt puudub apokrüüfis ka koera karistamise motiiv.

\section{Tekstid esimeste inimeste nimede ja inimeste teistkordse loomise}

\section{kohta}

Liivlastel leidub inimese loomise kohta algupärane dualistlik legend, mille toome ära täismahus.

Ükskord jumal mõtelnud, et oleks vaja teha naine ja mees. Jumal võtnud kaks savitompu ja ütelnud: "Saagu Aadam ja saagu Eeva!” Jumal ise läind minema ja mõtelnud, las nad tulgu toime. Kuid kurat vaadand põõsastes ja kuulatand, mis jumal ütleb. Ta kuulnud, et jumal ütleb "dam", kuid mis "dam", seda ta pole kuulnud. Niipea kui jumal saand põõsastesse, kohe kurat põõsaist välja ja savitompude juurde ja ütelnud: "Saagu dam-dom (= sandarm) ja saagu Eeva!” Ja niipea kui ta need sõnad ära ütelnud, kohe olnud ka jumal põõsaist väljas ja joosnud kuradi juurde. Niipea kui kurat seda näind, kohe ta hakand jooksma kuipalju vaid suutnud, kuni ta saand ära põgeneda jumala eest maa alla nende kahega - sandarmi ja Eevaga. Kuid otsekohe, kui kurat joosnud maa alla, jumal olnud kah juures ja saand Eeval pääst ühe tüki savi välja kiskuda. Ja nii ta teind otsekohe sellest savist ühe mehe üles, teise naise. 
Kuid tal pole tulnud enam nõnda suur, kui ta esiteks tahtnud teha: jumalal pole enam savi olnud. Nõnda ta teind, kui suur tal välja tuleb, ja sellepärast me oleme ka praegu sellised vähemad kui enne - kui kurat ei varastanuks ära neid esimesi inimesi! Jumalal olnud vähe tegemisasju; sellepärast ta teind, mis sääl ainult olnud: pää pääl on juuksed ja reite vahel kah-ükskõik, kas mees või naine (Loorits 2000: 146-147; Loorits 1926a: US $16+25)$.

Tekst on humoristliku ja isegi mõnevõrra satiirilise kõlaga, mis puudutab muu hulgas nime valesti kuulmist: kurat ei kuulanud lõpuni, mis nimed Jumal inimestele pani ja olles nende toorikutega põgenenud, nimetas nad sandarmiks ja Eevaks. "Sandarmi" jõudis ta seejuures maa sisse peita, Eeva peast aga teeb Jumal uue paari inimesi. Seega sisaldab tekst veel ka koomilist kirjeldust politsei aukraadi päritolust. ${ }^{12}$ Nimesid Aadam ja Eeva kasutatakse humoorikalt ära ka vene legendis: äsja loodud mees osutab Eevale ja hüüatab üllatunult: "Eeva!” Eeva aga pilgutab talle silma ja lubab: “A, dam!” Karistuseks nimetab Jumal nad nende nimedega (Belova \& Kabakova 2014: 242-243). ${ }^{13}$

Mis puudutab inimeste teistkordset loomist, siis selle motiiviga leidub paralleele slaavi, läänemeresoome ja ka juudi traditsioonides. Juudi rabinistlikes allikates võib kohata mainimisi, et Eeva loodi mitu korda. Ja Aadam ütles: "See on nü̈̈d luu minu luust ja ja liha minu lihast" (1Mo 2:23). Seda salmi on kommenteeritud järgmiselt: "Esimene kord Aadam nägi kõiki naise loomise üksikasju: veri ja soolikad ning põrkus vastikusega tagasi. Siis loodi Hava teist korda sel ajal, kui Aadam magas, ja näitas teda Aadamale juba valmis kujul ja Aadam jäi rahule" (Bereshith Rabba 18: 4). Mõlemal vaatlusalusel rahval luuakse inimest mitu korda, sest esimesed inimesed loetakse praagiks.

\section{Sabast loodud naine}

Eesti ja Valgevene rahvaluulest leiab versioone, milles naine loodi koera, aga ka Aadama, ahvi, kuradi sabast (vt ATU 798).

Kui Jumal oli tahtnud hakata looma naist, siis oli võtnud Aadama luu. Oli lõiganud suure noaga tüki välja. Läinud natuke eemale. Koer tulnud ja varastanud luu. Jumal hakand koera taga ajama, aga koer olnud väle jooksma. Jumal pole kuidagi koera kätte saand. Viimaks saand koera sabast kinni. Lõigand noaga selle ära. Ja loond sellest naise. Koer läks kondiga oma teed (ERA II 1, 382 (75) < Tartu 1 - Paul Ariste < Oskar Gnaderteich (1927)).

Eestis on see versioon naise loomisest väga populaarne (vt kaarti 1). 


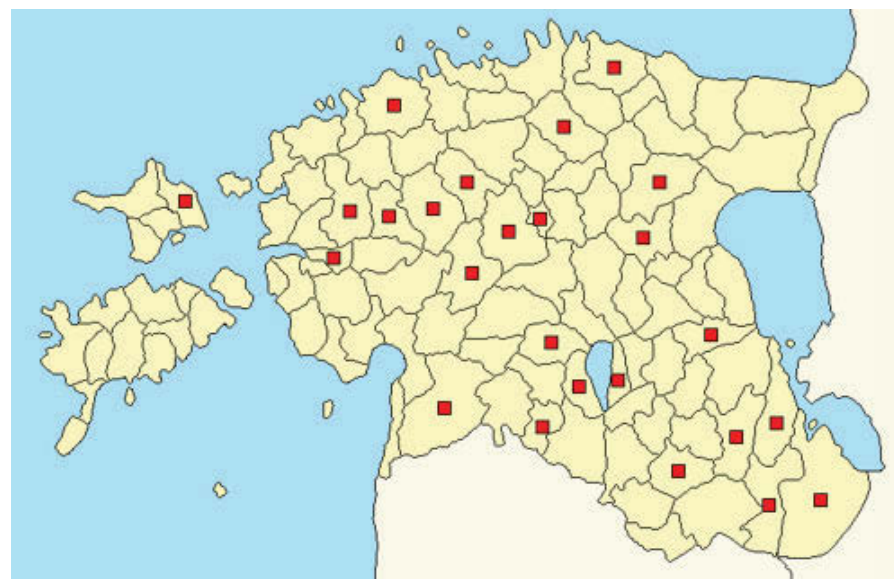

Kaart 1. Laialt levinud motiivi - koera sabast loodud Eeva levik Eestis. Kaart M. Kõiva.

Erinevates eesti versioonides tulenevad kirjeldatud sündmusest kõikvõimalikud lisaseletused naise olemuse kohta: naine kõigi oma omadustega on teist tüüpi olevus; naised kuulavad ainult poolt meeste juttu ja vaidlevad sageli; naised on eputised ja flirtijad (keerutavad mehi nagu koer saba); naistel, nagu koertelgi, on palju kirpe; naised, nagu koeradki, liiguvad kiiresti ja kipuvad hammustama jne.

Lätis Daugavpilsi rajoonis kirja pandud valgevene legendis (see versioon on kõige lähemal antud eestikeelsele versioonile ja loomulikult lähedane liivi variandile) võtab Jumal Aadamalt ribi, paneb kuivama, koer kahmab ribi hambu ja jookseb minema. Inglid ajavad koera taga kuni kõige noorem saab koeral viimaks sabast kinni, rebib selle küljest, toob Jumalale ja ütleb: "Ei ole just selline nagu vaja, aga üldiselt sarnaneb naisele, sest tal on luud, liha ja vill." Jutustaja lõpetab loo järgmise lausega: "Vaata siis, kuidas naine tehti sabast!" (Läti, Sahharovi arhiiv. Latviešu folkloras krātuve).

Lääne-Valgevenes pandi 19. sajandi lõpus kirja järgmine versioon: Jumal lõi Aadama alguses ilma sabata; pärast hakkas jumal mõtlema, et tegi halvasti, sest kõigil - loomadel ja inimestel - peab olema oma saba. Ta uinutas Aadama, lõikas talle saba ja asetas selle ta kõrvale maapinnale, et teha sellest naine Eeva. Nii et naised on loodud meeste sabast (Federowski 1897: 201). Ühes Valgevene variandis räägitakse, et kui Eeva Aadama sabast välja kasvas, olid nad veel mõnda aega sellega abil üheks tervikuks ühendatud, kuni saatan Eeva kiusatusse viis. ${ }^{14} \mathrm{Ka}$ siin on paralleele juudi traditsiooniga. Midrash Bereishit 
Rabbahis kirjeldatakse naise loomist kui tema lahutamist Aadama seljast, mis tähendab, et algselt oli inimene androgüünne olend. "Kuni Aadam magas, eraldas Hashem Aadama selja külge kinnitatud naiskeha ja asendas temalt sel moel ära võetud osa ihuga. Selline tõlgendus tuleb värsireast (Tehillim 139: 4) Ahor vakedem cartani - "Tagant ja eest (s.t topeltolendina) oled sa mu loonud (Rashi, Ketubot)" (Bereishit Rabbah). Tasub märkida, et Talmudis tähendab sõna "ribi" ka sõna "saba", millest võiski selline variant tulla (Kaspina 2001).

Seda süžeed on korduvalt registreeritud kõikjal idaslaavlaste juures (vt VESiL 2019: 415-418) ja süžee publikatsioone on olemas Soomes, Prantsusmaal, Portugalis ja Ladina-Ameerikas (ATU 798).

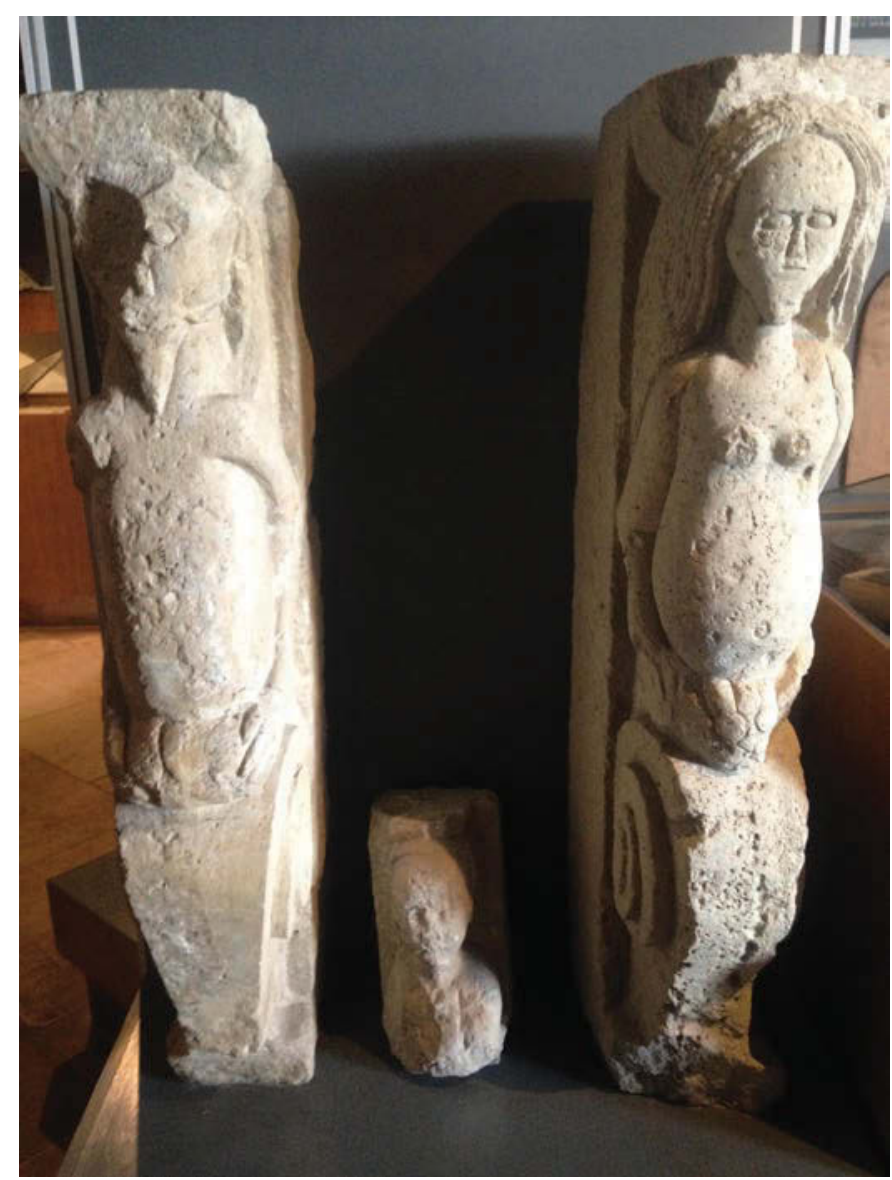

Foto 1. Aadam ja Eeva. Maasilinna maalinna varemetest leitud kujud on hoiul Saaremaal Kuressaare lossis. Aadma ja Eeva sugu pole kujudel kuigi täpselt määratletud. Mare Kõiva foto 2018. 


\section{Piibli ümberjutustused ja makrosüžeed}

Eesti ja Valgevene traditsioonides on esimeste inimeste Aadama ja Eevaga seotud tekstid tihti Piibli teksti ümberjutustused (Mo 1-3). Mõnel juhul on tekst piiblifragmendi põhisisu edasiandev kopeeriv ümberjutustus. Kuid rahvaluuletraditsioonide seisukohast on Piibli originaal liiga lakooniline ja vajab üksikasju, täpsustusi, selgitusi jms. ${ }^{15}$

Vaatleme näitena järgmist eestikeelset teksti, milles ühinevad esimesi inimesi käsitleva makroloo kõik kolm osa: nende loomine, pattulangemine ja elu pärast pattulangemist.

Jummal edimält lõi Aadama, pand teda paradiise elamä. Näit, et täl ütsindä nigo kurb elo. Pand sis magama, võtt kurapoolidsõ küleluu, murd otsa maaha ja tekk tuust tälle Eeva.

Nü̈̈d and sis näile luba kõikõ süvvä, ainult sis ütest puust kiild, et siis söögui. Ja nü̈̈d elleväl ihokatõt vaja es olõ, iho oll nigu kü̈̈ds, ta om mälehtüsmärgist jäänü. Linnä keske muu sisse es saa. Huss võtt vanahalva suuhtõ ja vei aida. Sis timä sä̈̈lt hussi suust kõnõlas: "Mis tii pelgät. Ta Jummal kadõdõsõ peräst kiild. Ku ti tast sü̈̈de saat tii ka niisama targast ku timä.” Es kärsihe Eeva, võtta vaja pruuve. Võtt sis üte pruumõ ja and ka Aadamalõ. Nüüd sis jäivähe ihoalastõ, naas häbü ja lätsivä puhmu sisse. Naksivä sis puu lehist häbehüste kotsele palmitsõma lehekesist põllo, muido oll nigu ilodo olla. Jummal tull ja hõikas. "Aadam koh sa olt." Tuu ei tihka hellü tetä! Hõikas tõõsõ kõrra, sis tege helü vasta. "Tulõ vällä!” ütles - "Mi sai tullä." - "Misläbi sis sa lätsidõ üle keelo?” Aadam ütles, et mis sa annidõ abilitse ma ka es saa muido.

Küsse sis Eeva käest, et mis läbi sa võtide. Eeva ütles, et mullõ huss and, tuuperäst ma võti.

Sis võtt hussi, kaksas katske, viss merre ja pää jätt maa pääle. Ai sis nimä ka aiast vällä. Mehele ütel, et sullõ sa püha ka, a naistõrahvalõ sai pähhä ka, muido vallu ka piä saatma tahest. Last piat ilma tuuma suurõ valuga, koh saa sis naistõrahvas husse nägemä, sis piät pää rõuhkkma purust, koh sa sis tapus olõma sääl, sis ka matas.” Ai nimä paradiisist vällä muidoge ja pand Keerobedsõ ingle tulidsõ mõõgaga värehte pääle. Tuu parhillahe on sä̈̈l (ERA II 163, 82/4 (19) < Setumaa, Järvesuu v, Värska - Nikolai Ress < Aleksei Mägioja, 62 a (1937)).

Selles tekstis saame eristada süžeede kompleksi, mis ühendab orgaaniliselt nii piibellikke (tähistatud viidetega kirjakohtadele ja raamatutele) kui ka vernakulaarseid, folkloorseid motiive. 
- Jumal loob Eeva Aadama küljeluust (Mo 1:15-25);

- Enne pattulangemist oli esimeste inimeste keha küüntest (rahvalik motiiv);

- Kurat palub maol end suhu võtta ja suus paradiisiaeda toimetada (rahvalik motiiv);

- Kurat viis Eeva kiusatusse ja Eeva Aadama (Mo 3:1-6);

- Inimesed hakkavad oma alastust häbenema ja katavad keha lehtedega (Mo 3:7);

- Jumal jagab mao kaheks - üks osa jääb maa peale (madu), teise osa laseb ta merre (angerjas) (rahvalik motiiv);

- Naisel ei ole vaba aega, sest ta patustas esimesena (rahvalik motiiv);

- Naine toob lapsi ilmale valuga (Mo 3:16);

- Madu nähes peab naine tema pea lömastama (Mo 3:15).

Makrolugu ühendab tervikuks mitmed motiivid, mis harilikult esinevad iseseisvate narratiividena. Kuigi jutuvestmise situatsioonis esinesid makrolood ilmselt sagedasti, on üleskirjutustes valdavad üksikmotiivid.

\section{Esimeste inimeste küüntest kehad}

See, et esimeste inimeste kehad olid küüntest, sarvest või soomustest, on traditsiooniline motiiv eesti ja valgevene folklooris ja enamasti esineb see iseseisva jutuna. 19. sajandil on seda kirja pandud Valgevene idapoolsetes (Dobrovolski 1891: 236) ja läänepoolsetes piirkondades (Federowski 1897: 201). Seesama küüntest (sarvest) keha motiiv on omane mitte ainult Valgevene, vaid ka Ukraina, Põhja-Venemaa, Poola, Leedu ja Bulgaaria folkloorile (Bulašev 1992: 103; Belova 2004: 239-241; Zowczak 2013: 97; Badalanova Geller 2017: 369-371) ning paralleele sellega leiab juudi allikatest (Kaspina 2000: 125-126). Poola juttude põhjal saame üldistada, et küüntest keha on sile ja tugev (nagu olid savist voolitud inimesed nende loomise alguses) ning varjab naise ja mehe sootunnuseid (Zowczak 2013: 97). Kui küüntest keha aga pärast pattulangemist maha pudenes, tuli selle alt välja "patune ihu" - soolised erinevused. Paljudes valgevene tekstides rõhutatakse "patuse ihu" (suguelundite) tekkimist ja olemasolu just pärast pattulangemist. Paralleelne vaade esineb ka talmudi traditsioonis, kus ühelt poolt on tuntud idee Aadamast kui algselt androgüünsest olendist, teiselt poolt, et esimesed inimesed olid aseksuaalsed (Tokarev 1991: 395).

Esimeste inimeste küüntest kehadega on seotud uskumus, mida kohtab nii Valgevenes kui Eestis, et lõigatud küüsi ei tohi laiali loopida: pärast surma tuleb nende abil ronida kõrge mäe otsa Jumala juurde paradiisi või viimsepäevakohtu ette. See uskumus on laialt levinud paljude rahvaste seas - näiteks 
leiame selle juutide, slaavlaste, baltlaste, skandinaavlaste hulgas (Bulašev 1992: 103; Levkijevskaja 2004: 427; Volodina 2018: 181-206).

Motiiv küüntest keha kohta on Valgevenes populaarne Ülem-ja Alam-Dnepri ja Ida Polesje piirkonnas, samuti Ponemanie ja Dvina aladel. 19. sajandil pandi Lääne-Valgevenes kirja uskumus, et kui inimene pillub eluajal oma küüned laiali, ei pääse tema hing pärast surma ei taevasse ega põrgusse, vaid jääb karistuseks ${ }^{16}$ toonekure kujul maad mööda käima, kuni kogub äravisatud küüned kokku ja alles siis, kui kõik on koos, muutub inimeseks ja läheb taevasse.

Kes pillub lõigatud küüned maha, selle hing ei lähe pärast surma taevasse ega põrgusse, vaid kõnnib jumala tahtel toonekurena ringi kuni on kõik lõigatud kü̈̈ned kokku kogunud (Federowski 1897: 221).

Kui kurg on kõik küüned kokku kogunud, muudetakse ta uuesti inimeseks ja ta saab taevasse, sest tema karistus on läbi. (Federowski 1897: 185).

Eesti usundis keelatakse lõigatud küünte laialiloopimist, sest neist teeb kurat endale nähtamatuksmuutva kübara.

Motiivide levikut Valgevenes ja Eestis vt kaartidelt 2 ja 3.

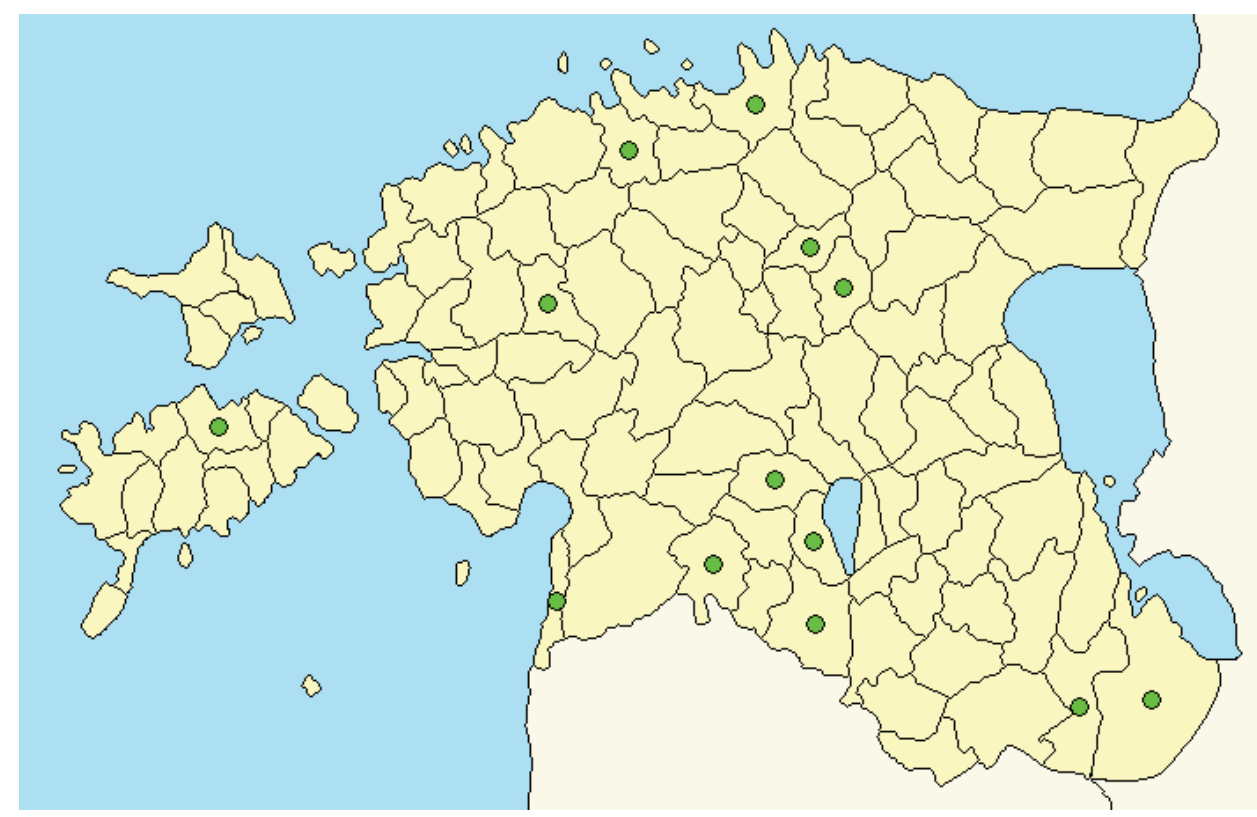

Kaart 2. Esimeste inimeste kü̈̈ntest kehad (motiivi levik Eestis). Kaart M. Kõiva. 


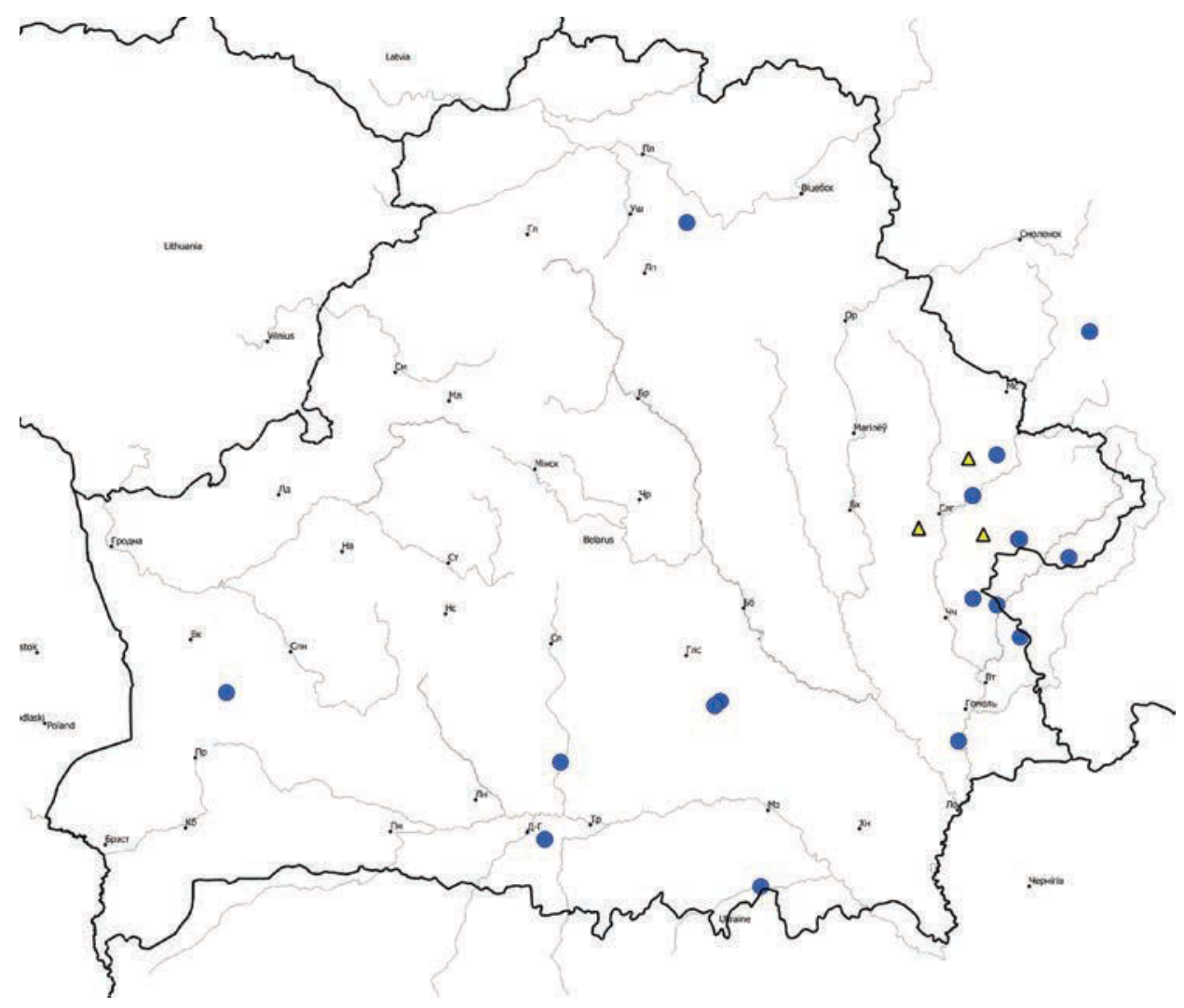

Kaart 3. Esimeste inimeste küüntest kehad ja küünte laiali loopimise keeld (motiivide levik Valgevenes). Kaart T. Avilin.

- kü̈̈ntest kehad

$\triangle$ - kü̈̈si ei tohi laiali loopida, sest nende abil tuleb pärast surma ronida mäe otsa

\section{Mao, angerja ja vingerja motiivid}

Eesti motiiv "Kurat palub maol end suhu võtta ja suus paradiisiaeda toimetada" on algupärane, st slaavi traditsioonides ei ole sellel analooge. See motiiv on üksikasjalik kujundlik illustratsioon universaalsele kontseptsioonile, milles ahvatleja madu samastatakse kuradiga.

Motiivi mao kaheks jagamisest - üks osa jääb maale (madu), teine ujub meres ja muutub angerjaks - kohtab Eesti etioloogiates kõige erinevamates variatsioonides, kus Jumal/Jeesus/Mooses mao erinevatel põhjustel pooleks raiub (vt Etioloogiad 2021).

Mõnes eesti ja nt lutsi etioloogias tekivad madu ja angerjas ühe köie kahest otsast: ühe otsa äratab kurat ellu, temast saab madu, kes kuradit salvab, teise 
otsa äratab ellu Jumal, see muutub angerjaks, kes ei tee loojale häda isegi siis, kui too ta kätte võtab (ERA II 162, 9/11 (1) < Lutsi - P. Voolaine (1935)).

Leedu legendis toppis angerjas oma kehaga kinni augu paadis, milles sõitis Jeesus ja sellest ajast alates võivad inimesed teda toiduks tarvitada, kuigi ta sarnaneb maoga (Belova \& Kabakova 2014: 148-149).

Valgevenes on angerjas haruldane kala ja seetõttu valgevenelastel angerja kohta legende pole, aga on vingerjast - mao või väikese angerja sarnasest mageveekalast. Valgevenelastel on vingerja päritolu kohta kaks versiooni: 1) vingerjaks muutub nael, mille mustlane Kristuse ristilöömiselt varastas ja jõkke viskas (Boganeva 2010: 119-120); 2) Kristuse ristilöömisel anti talle nastikuid süüa. Kristus muutis need nastikud vingerjateks ja ütles, et nüüd kõlbavad need inimestel süüa.

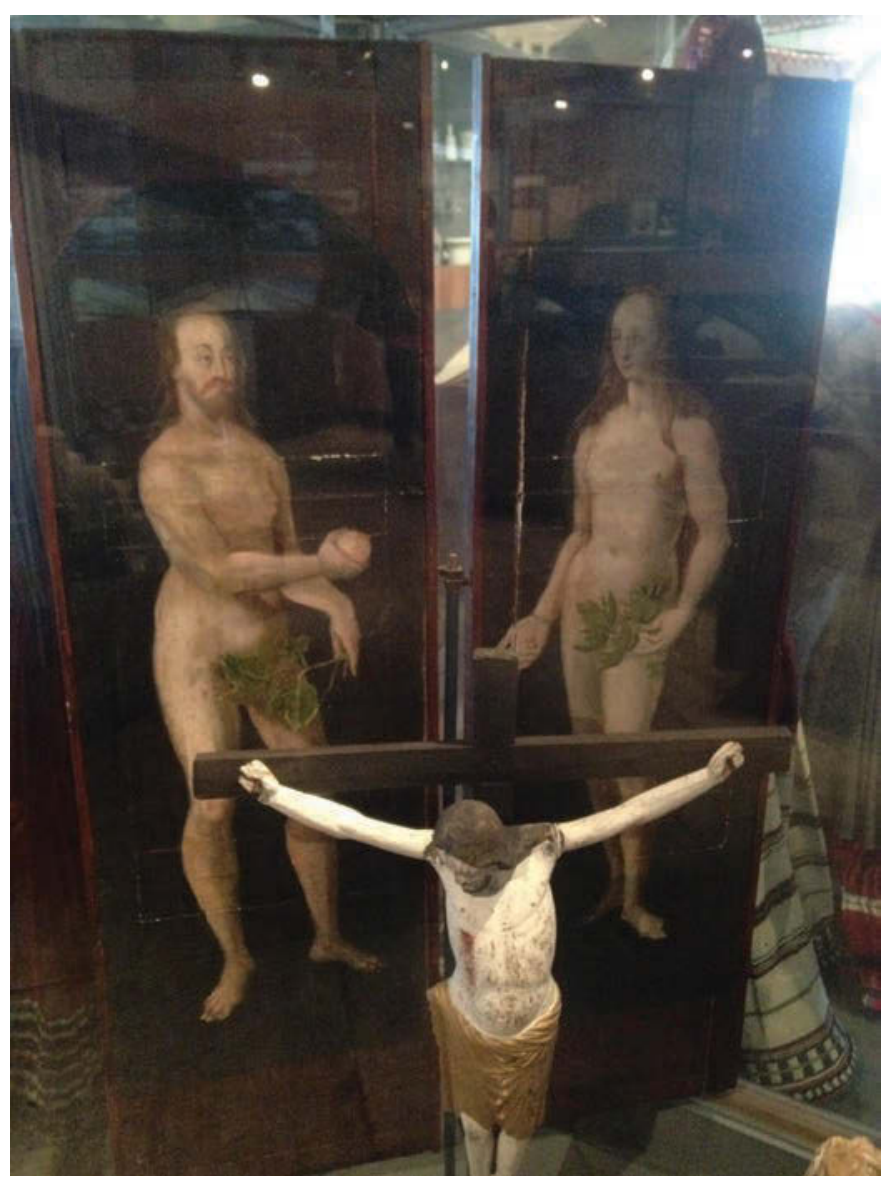

Foto 2. Aadam ulatab Eevale õuna. 13. sajandil rajatud Kaarma kiriku altari tiivad; hoiul Saaremaal Kuressaare lossis. Mare Kõiva foto 2018. 
Ma olen ainus, kes vingerjast [jutte] kuulis. Ma kuulsin, mida meie inimesed rääkisid. Isegi mu ema, kui nad tõid meie kala, ja vingerjas saagi hulka sattus: "See on uss!" - Vingerjas on uss. Kui teda [Kristust] risti löödi ja teda piinati igat moodi, siis anti Kristusele usse, anti toiduks usse. Tema lähedal olid inimesed - tema inimesed. Ja ta ütles, pöördus nende poole ja ütles: “Sööge, ärge kartke!” Ja ta andis ussile kaks tagumist otsa, ühte ja teise otsa, ja oligi kõik. Tal pole sellist kala saba, vaid ta on tõeline uss.

"Sööge, ärge kartke. Kes sööb, see usub minusse."

Seda ma kuulsin. Ja ütles: "Lihtsalt lõigake pea otsast, sest pea hammustab. Lõika pea ära ja söö ülejäänut, ära karda.”Vaat seda kuulsin ussi kohta. ${ }^{17}$

Nagu märgata võib, sarnaneb vingerja päritolu käsitleva legendi teine versioon Eesti etioloogiaga angerjast: vingerja saamislugu on sarnane angerja saamislooga - üks tekib nastikust, teine maost ja mõlemad jäävad sarnanema oma eellasega.

\section{Miks on naistel alati tööd}

Motiiv, et naisel ei ole kunagi vaba aega, sest ta patustas esimesena, on ühtviisi levinud nii Eesti kui ka Valgevene pärimuses. Valgevenelaste seas kohtab aga sagedamini etioloogiat, mis on seotud mitte esimeste inimeste, vaid rändava Jumalaga. Kui Jumal maa peal ringi rändas, palus ta naisel endale teed näidata, kuid naine rügas tööd ega sirutanud selgagi, vaid näitas jalaga, kuhu suunas minna. Mees aga katkestas töö ja viis Jumala õigele teeotsale. Sest ajast peale on naistel alati tööd. Tänapäevastes kirjapanekutes on sellest süžeest arvukalt versioone, mis on avaldatud Valgevene raamatusarjas "Valgevenelaste traditsiooniline kunstiline kultuur” (TMKB 2006 (2): 370-372; 2009: 434-435; 2011: 445-447; 2013: 605-607). Sellest legendist leidub ka eestlastel variante. Setu variant kõlab valgevene tekstiga sarnaselt, kuid legendis määrab Kristus laisale mehele virga naise, et nad "saaksid ilmas ära elada":

Krystus käve maad pit'e, kat'stõis'küme sulast ol'l täl muidogi üt'eh. Lä̈̈väq tiid pit'e, tüt'rik säl'lülde maah tii veereh. Krystus küs'se tiid, timä näüdäs' jalagaq. Midägi tuust, lät'siq mü̈̈dä arq. Lääväq palakõsõ maad, tsura äestäs tii veereh. Küsüse tuu käest tiid jalq. Tuu jät't hobõsõ saisma, vei Krystusõ tuu teeharo pääle, kohe tä küs'se. Sulasõq üt'liq, kost taalõ tsuralõ hüvvä mõr'sjat saa, taalõ vaia hüvvä mõr'sjat. Krystus üt'el, taa ol'lgi timä mõr'sja, taa saagi täl'le mõr'sjast, kiä säl'lülde maah ol'l. 
Foto 3. 17. sajandil Dubrovo linnas elanud valgevene puulõigete meistri Vassili Koreni poolt pärnapuust tahvlile lõigatud Moosese raamatu ja Apokalüpsise motiivid. Vassili Koreni piibel oli tähtis kirjaoskamatu lihtrahva jaoks. A. Boganeva kogu.

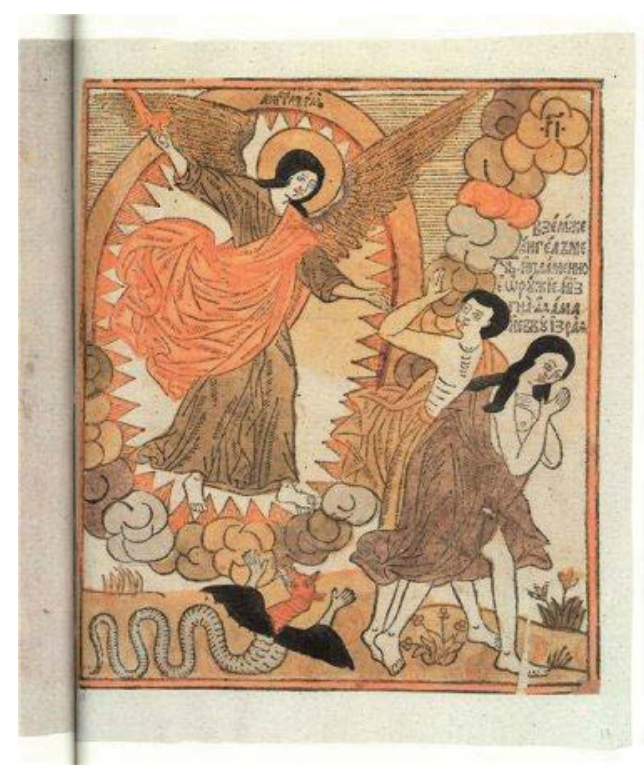

Nimäq saavaq syss ilmah ar elläq, ku üt's laisk, tõõnõ virk (ERA II 286, 168/9 (146) < Setu, Petseri v, Säpina k - Ello Kirss < Anastasia Kuus, snd 1860 (1940)).

Ka Eestis kohtab motiivi naise häbematust vastusest rändava Jumala tervitusele, millest saadik ei lõpe naistel töö kunagi otsa. Veel üks eesti versioon naiste pidevast tööst on seotud asjaoluga, et naine ei ava Kristusele väravat, kui too Jeruusalemma tuleb (vrd ka ülalnimetatud motiiviga naise põhjendamatust palvest endale ka pühapäevaks tööd saada).

\section{Esimeste inimeste surm}

Setudel on tekst Aadama surmast, mis on mõjutatud raamatuallikast.

Ku Eeva Aadamiga elli ja jo vana' olli’, syss Essä ütel perrele, et ku teil vanamees koolõs ar', syss ülge mullõ ka'. Kooli ar', ni' teed kuis nä' sai tälle ütlema, a ar' käve ütlemah. And kol' teräkeist taivast, et ku ar' matat, külbke noo’ kääpähe. Nimäq nii teiq ka'. Kasvi ulli-illos' puu, kolmõharoline. Tuu saigi Jeesusõlõ ristist.

Kasvi väega ilosast, ni’ kuningas võt't, niq las'k kerigu pingi tetä. Kuningas lätt hommogu pinki pühendämä, a vapanaasele nä̈̈däs ü̈̈se unõh, et mine, istu pingi pääle. Sa olt õndsamb ku kuningas. Timä nii 
tekk ka'. Kuningas lätt, ni’ näge ar'ki alt paja, et vanainemine pingi pääl istus. Põlg pingi ar, ni’ hiit’ kerikust vällä. Rahvas käve sääl hinnäst ravitsõmah. Kuningas käsk hiitä mõtsa ar'. Rahvas käve õks sinnä. Ni' säält saigi Jeesusõlõ rist. Ku tuu kuningas põlgnu-us ar', ni' saanuki-is (ERA II 194, 479/80 (16) < Setu, Petseri v, Risjova k - Ello Kirss < Tat'o Kallaste, snd 1875 (1938)).

Selles tekstis on ilmne vihje apokrüüfile "Ristipuust", mille autorlus omistati pühamehele Pühale Gregoriusele (ehk Grigori Dvojeslovile) ning on tuntud serbia, bulgaaria ja vene allikate põhjal, mida eristavad keelelised iseärasused (vt apokrüüfi kohta Fedorova 2012: 89-107).

Valgevenelastel ja poolakatel on tuntud kuningas Saalomonist kõnelevate legendide sarjas jutustused prohvetnaisest Sibyllast (Sebiliya), kes keeldus kõndimast üle jõe või oja mööda puust purret, öeldes, et selle purde puust tehakse Kristuse rist (Boganeva 2015: 57-64). Valgevenes on seda süžeed registreeritud harva, samas kui Poolas on see laialt levinud (Zowczak 2013: 201).

Eestikeelsesse teksti ilmub algupärane kujund pingist, mis samastub üle jõe viiva purde kujundiga, nimetu kuningas aga kuningas Saalomoniga, kes figureerib tavaliselt prohvetnaise Sibylla (Sebiliya) kohta käivates legenditsüklites.

\section{Kokkuvõtteks}

Käsitlesime ainult mõnda eestlaste ja valgevenelaste motiivi esimeste inimeste kohta ning selgitasime välja rea nii ühiseid kui ka lokaalseid algupäraseid motiive. Mõistetavalt on tegemist väikese osaga kogu ainestikust. Esialgselt tundub, et setu pärimuses leidub vasteid slaavi õigeusu traditsioonile ja PõhjaVenemaal levinud tekstidele. Laiemalt Euroopa traditsioonis tuttavad motiivid on levinud sisuliselt kogu Eestis, küsimus on pigem üleskirjutuste arvus. Isegi üksikute motiivide vaatlusel on nähtavad laialt levinud universaalsed tüübid. On ilmne, et jutustaja võis tervikuks liita rea lühemaid süžeid, millest osa on Piiblil põhinevad ja teine osa rahvapärased universaalsed arendused, mis ilmnes seto ja valgevene üleskirjutustest. Väga ilmne on sama motiivi või teema esinemine erinevates rahvaluuleliikides, igal neist on oma liigilised normatiivsed reeglid, kuid nad toetuvad samale alusmotiivile või kirjakohale.

Eestlastele ja valgevenelastele ühiste etioloogiliste motiivide näidete varal, näiteks "Miks naisel on alati tööd", tuleb selgesti välja etioloogiliste süžeede piibliteemadega kohandumise mehhanism. Teatud etioloogiad võivad piiblisüžeede ruumis suhteliselt vabalt liikuda ja luua uusi seoseid, rikkumata ühe või teise etioloogia sisemist loogikat ja loomata sellest tulenevat uut teksti. 
Ei saa kuidagi jätta kõrvale seoseid erinevate tekstitüüpide ja kunstiliikidega - usundilised jutud on Piibli kõrval saanud mõjutusi suulisest folkloorist ja trükistest, aga neid on mõjutanud ka visuaalsed kunstid, mis on omaette suurem teema ja millele vihjavad ka artikli illustratsioonid.

Valgevene ja Eesti rahvaluulelisi sidemeid on seni äärmiselt vähe uuritud. Edasised uuringud võimaldavad kindlaks teha mitte ainult ühised ja erinevad motiivid eestlaste ja valgevenelaste mütoloogias ja folklooris, vaid perspektiivis uurida üksikasjalikumalt kultuurilisi ja transkultuurilisi ühisjooni. Samuti vaadelda hüpoteesi balti ja soome-ugri substraadist valgevenelaste etnogeneesis.

\section{Tänuavaldus}

Uurimistööd toetas EU Regionaalarengu Fond (Eesti-uuringute Tippkeskus, TK-145) ja EKM uurimisprojekt "Folkloori usundilised ja narratiivsed aspektid" (EKM 8-2/20/3, EKKD65).

\section{Kommentaarid}

1 Slaavi ja soome-ugri muistendite võrdlemisele on pühendatud O. Belova artikkel, milles soome-ugri muistendeid käsitletakse peamiselt komi rahva materjalide põhjal (Belova 2007: 229-241). Lisaks on vene keeles olemas veel terve hulk komi müütidele ja legendidele pühendatud raamatuid ja artikleid (Limerov 2005, 2012; Šarapov 1996; Smirnova \& Tšuvjurov 2002; Kuznetsov 2018 jt).

2 Vt folkloristide uurimissuundade kohta lähemalt Ziolkowski 2017; Niditch 2018.

3 Eesti etioloogiate suurem kataloog on töös, ka selle artikli alusmaterjal hõlmab laiemat teemade hulka ja on leitav kataloogis Eesti etioloogiad (alusmaterjalid www.folklore. ee/etioloogiad).

4 AaS - Antti Aarne kataloogi muistenditüüpide nimetuse lühend (Aarne 1918).

5 Valgevene kultuuri, keele ja kirjanduse uurimiskeskus RTA, J. Kolase ja J. Kupala nim keeleteaduse instituut, etnolingvistika ja folkloristika osakond.

6 E. Boganeva ja T. Varfolomejeva salvestised 2007. aastast 1939. aastal sündinud Larissa Guleitšikult, Kamenka k, Uzdenski raj, Minski obl.

7 Näiteks on Eesti arhiivis korduvad kirjapanekud legendist, kuidas naine pühapäevaks tööd sai. Vanatüdruk palus Jumalalt pühapäevaks tööd. Jumal soovitas tal palvetada, naine aga vastas, et ka siis jääb liiga palju aega üle. Siis raputas Jumal talle pähe peotäie tuhka, mis muutus täideks - nüüd on naisel ka pühapäeval tööd (H I 4,724 (6) < Otepää - J. Vuks (1879); ERA II 54, 224/5 (247) < Tartu-Maarja, Kavastu k).

8 Kuna eesti etioloogiaid esimeste inimeste kohta peaegu ei ole avaldatud, toome ära mõned tekstid tervikuna, osa tekste on antud ümberjutustustena. 
9 Slaavlastel on dualistlike legendide kohta on avaldatud laialdaselt kirjandust. Ülevaadet dualistlike legendide uuringute kohta vt: Kuznetsova 1998; Belova 2004: 44-57; Belova \& Petruhhin 2009: 312-323; Badalanova 2008: 235-242; 2011: 134-136; Badalanova Geller 2017: 23 jt).

${ }^{10}$ Legendi on kirja pannud M. Federowski 19. sajandi lõpus Lääne-Valgevenes (Federowski 1887: 200, nr 780).

11 Rumjantsevi 17. sajandi kogumikust.

${ }^{12}$ Arvestades, et sandarmikorpuste aktiivne tegevus Venemaal ja teistes Euroopa riikides algas 19. sajandil, võib teha järelduse, et läänemeresoome aladel olid 19. sajand ja 20. sajandi algus veel etioloogiate aktiivse kujunemise aeg.

${ }^{13}$ A, dam - seksuaalse konnotatsiooniga keelemäng, vene keelest tõlkides: Jah, annan! Legendi üleskirjutus pärineb 19. sajandi lõpust Novgorodi kubermangu Tšerepovetsi kreisist (praegune Vologda oblast) (Belova \& Kabakova 2014: 427). Eesti legendide ja mütoloogiliste tekstide paralleele leiab sageli just Venemaa põhjapoolsete piirkondade legendides ja müütides.

${ }^{14}$ Vt Seržputovski 2009: 62.

${ }^{15}$ Piibli ümberjutustuste kohta vt (Boganeva 2010: 4-13; 2014: 116-125).

${ }^{16}$ Pakuta - kehaline või hingeline piin, siin - karistus, katoliiklastest valgevenelased ja poolakad nimetasid pakutaks sageli patukahetsust, moraalset parandusabinõu.

${ }^{17}$ E. Boganeva, N. Petrovi ja N. Savina salvestis 2014. aastast Marina Romanenkolt (sünd 1922) Žuraveli k, Mogiljovi obl.

\section{Arhiiviallikad}

Skriptoorium, digitaalne etioloogiate kogu, mis sisaldab digiteeringuid EKM Eesti Rahvaluule Arhiivist

Käsikirjad Eesti Kirjandusmuuseumi Eesti Rahvaluule Arhiivi (ERA) kogust (1927-1945)

$\mathrm{H}$ - Jakob Hurda käsikirjaline rahvaluulekogu

Valgevene RTA Valgevene Kultuuri, Keele ja Kirjanduse Uurimise Keskus

BFELA - Valgevene folkloori ja etnolingvistika andmebaas

\section{Kirjandus}

Aarne, Antti 1918. Estnische Märchen- und Sagenvarianten: Verzeichnis der zu den Hurt'schen Handschriftsammlungen gehörenden Aufzeichnungen. FF Communications 25. Hamina: Suomalaisen Tiedeakatemian Kustantama.

ATU = Uther, Hans Jörg. The Types of International Folktales. A Classification and Bibliography 2004. Based on the System of Antti Aarne and Stith Thompson by HansJörg Uther. 1-3. FF Communications 284. Helsinki: Finnish Literature Society. 
Badalanova, Florentina 2008. The Bible in the Making: Slavonic Creation Stories. Geller, Markham \& Schipper, Mineke (toim). Imagining Creation. Leiden \& Boston: Brill, lk 161-365 (doi: 10.1163/ej.9789004157651.i-424.37).

Badalanova Geller, Florentina 2011. The Sea of Tiberias: Between Apocryphal Literature and Oral Tradition. Di Tommaso, Lorenzo \& Böttrich, Christfried (toim). The Old Testament Apocrypha in the Slavonic Tradition: Continuity and Diversity. Tübingen: Mohr Siebeck Gmb, lk 13-157.

Badalanova Geller, Florentina 2017. Kniga sushchaia v ustakh. Fol'klornaia Bibliia bessarabskikh i tavricheskikh bolgar. Moskva: Russkii fond sodeistviia obrazovaniiu i nauke.

Belova, Olga 2004. "Narodnaia Bibliia”: Vostochnoslavianskie etiologicheskie legendy. Moskva: Indrik.

Belova, Olga 2007. Bibleiskie legendy v kul'ture slavianskikh i finno-ugorskikh narodov. Slavianskii al'manakh, lk 229-241.

Belova, Olga \& Kabakova, Galina 2014. U istokov mira. Russkie etiologicheskie skazki i legendy. Moskva: Forum; Neolit.

Belova, Olga \& Petruhhin, Vladimir 2009 = Belova, Olga \& Petrukhin, Vladimir. "Vremia tvoreniia": Dualisticheskaia kosmogoniia v svete fol'klornoi tekstologii. Belova, Olga (vast toim). Istoriia - mif-fol'klor v evreiskoi i slavianskoi kul'turnoi traditsii. Sbornik statei. Moskva: Probel, lk 313-323.

Ben-Amos, Dan 1972. Toward a Definition of Folklore in Context. Paredes, Américo \& Bauman, Richard (toim). Toward New Perspectives in Folklore. Austin: University of Texas Press, lk 3-15.

Ben-Amos, Dan 2009. Žanrikontseptsioonid folklooris. Ben-Amos, Dan. Kommunikatsioon ja folkloor. Sator 9. Tartu: EKM Teaduskirjastus, lk 117-138.

Berezkin, Juri \& Duvakin, Evgenii 2020. Tematicheskaia klassifikatsiia i raspredelenie fol'klorno-mifologicheskikh motivov po arealam. Analiticheskii katalog (http://www. ruthenia.ru/folklore/berezkin/ - 28. juuni 2021).

Bereshit Rabba 2020. Kak v Erev Shabat byl sozdan Adam i pomeshchen v Gan Eden. Midrash rasskazyvaet (http://jhist.org/traditions/midrash003.htm - 28. juuni 2021).

BNB = Boganeva, Elena 2010. Belaruskaia "narodnaia Bibliia” y̆ suchasnykh zapisakh. Minsk: Belaruski dziarzhay̆ny y̆niversitet kul'tury i mastatstvay̆.

Boganeva, Alena 2014. Bibleiskiia vusnyia narodnyia perakazy: raznavidnastsi, tematyka, mekhanizmy fal'klaryzatsyi. Valodzina, Tatstsiana (peatoim). Belaruski fal'klor. Materyialy i dasledavanni. Zbor. navuk. prats. 1. Minsk: Belarus. navuka, lk 126-137 (https://ethno.by/artykuly/1416454092 - 28. juuni 2021).

Boganeva, Alena 2015. Sebilija jak persanazh belaruskai "narodnai Bibli” i zvjazanyia z ei narodnabibleiskia matyvy. Asoba zbiral'nika y̆ zahavanni nemateryial'nai kul'turnai spadchyny: da 200-goddzja z dnja naraddzhennia O. Kol'berga. Materyialy Mizhnarodnaga kruglaga stala; 25-27 chervenia 2014 g. Minsk-Pinsk. Minsk: Hursik, lk 57-65. 
Bulašev, Georgi 1992 = Bulashev, Georgi. Ukraïns'kii narod u svoïkh legendakh, religiinikh pogliadakh ta viruvanniakh. Kosmogonichni ukr. narodni pogliadi ta viruvannia. Kiïv: Dovira.

Dobrovolski, Vladimir 1891 = Dobrovol'skii, Vladimir. Smolenskii etnograficheskii sbornik. I. Sankt-Petersburg: Tipografia E. Evdokimova.

Dragomanov, Mihhail 1876 = Dragomanov, Mikhail. Malorusskie narodnye predaniia i rasskazy. Kiev: M. P. Fritz.

Dundes, Alan 1999. Holy Writ as Oral Lit: The Bible as Folklore. Lanham, MD: Rowman \& Littlefield.

Federowski, Michał 1897. Lud biatoruski na Rusi Litewskiej. Materiaty do etnografii stowiańskiej zgromadzone w latach 1877-1905. W 8 t. T.1: Wiara, wierzenia i przesqdy ludu z okolic Wotkowyska, Stonima, Lidy i Sokótki. Kraków: Wydawnictwo Komisji Antropologicznej Akademii Umiejętności.

Fedorova, I. V. 2012. Apokrify i istoricheskie predaniia v russkoi palomnicheskoi literature XII-XIX vekov: 1. Apokrify o Krestnom dreve. Russkaia literatura. Istorikoliteraturnyi zhurnal 3, lk 88-106 (http://lib2.pushkinskijdom.ru/Media/Default/PDF/ RusLiteratura/\%D0\%A0\%D0\%9B\%202012\%20n3.pdf - 29. juuni 2021).

Frazer, James G., Sir 1918. Folk-lore in the Old Testament: Studies in Comparative Religion and Law. 3 vols. London: Macmillan.

Grynblat, G. \& Gurski, A. 1983. Legendy i padanni. Minsk: Navuka i tekhnika.

Grynblat, G. \& Gurski, A. 2005. Legendy i padanni. 2. väljaanne. Minsk: Belaruskaia navuka.

Gunkel, Hermann 1987 [1917]. Das Märchen im Alten Testament. Frankfurt am Main: Athenäum [Tübingen: J. C. B. Mohr].

Hasan-Rokem, Galit 1990. And God Created the Proverb... Inter-generic and Intertextual Aspects of Biblical Paremiology or the longest way to the Shortest Text. Niditch, Susan (toim). Text and Tradition - The Hebrew Bible and Folklore. Atlanta: Society of Biblical Literature Semeia Studies, lk 107-119.

Hoffmeier, James K. \& Wenham, Gordon J. \& Sparks, Kenton L. 2015. Genesis: History, Fiction, or Neither? Three views on the Bible's Earliest Chapters. Zondervan Academic.

Kaspina, Maria 2000. Vospriiatie siuzheta o grekhopadenii Adama i Evy v evreiskoi i slavianskoi traditsii. Belova, Olga (vast toim). Kontsept grekha v slavianskoi i evreiskoi kul'turnoi traditsii. Sbornik statei. Sefer. Akademicheskaia seriia. Vypusk 5, lk 116-129.

Kaspina, Maria 2001. Siuzhety ob Adame i Eve v svete istoricheskoi poetikiю Na materiale drevnei i srednevekovoi evreiskoi i slavianskoi knizhnosti. Moskva: Russian State Humanities University.

Kirkpatrick, Patricia G. 1988. The Old Testament and Folklore Study. Journal for the Study of the Old Testament, suppl. ser. 62. Sheffield: JSOT Press.

Krikmann, Arvo 1986. Fraseoloogiline aines eesti vanimates grammatikates ja sõnastikes. Tallinn: Valgus. 
Krikmann, Arvo 1999. Eesti lühivormide allikaloost. Tartu: EKM (www.folklore. ee/ kriku/ALLIK - 15. juuli 2021).

Kuznetsov, Nikolai 2018. Sotvorenie zemli v komi mifologii. Kõiva, Mare \& Volodina, Tatjana (toim). Missiia vypolnima. Perspektivy izucheniia fol'klora. Tartu: ELM Scholarly Press. Tartu: ELM Scholarly Press, lk 169-180 (doi: 10.7592/Sator.2018.19).

Kuznetsova, Vera 1998. Dualisticheskie legendy o sotvorenii mira v vostochnoslavianskoi fol'klornoi traditsii. Novosibirsk: Izd-vo SO RAN.

Kõiva, Mare 2020. Molitva i zagovor. Bibleiskie motivy i kharatery v zagovorax. Volodina, Tatjana \& Kõiva, Mare (toim). Fol'klor i fol'kloristika. Vzgliad iz Belarusi i Estonii. Missiia vypolnima 2. Minsk: Belarusskaia navuka, lk 12-48.

Levkievskaia, Elena 2005. Mify russkogo naroda. Moskva: OOO Izdatel'stvo Astrel' AST (https://www.booksite.ru/fulltext/myt/hsr/uss/kih/index.htm - 30. juuni 2021).

Limerov, Pavel 2005. Sotvorenie mira. Mifologiia naroda komi. Syktyvkar: Komi nebög ledzanin.

Limerov, Pavel 2012. Boüдöp. Kogda-to. Mify, legendy, predanija komi naroda. Syktyvkar: OOO Izdatel'stvo Kola.

Lobach, Uladzimir 2011. Polatski etnagrafichny zbornik I-II. 2. väljalase. Navapolack: PDU.

Loorits, Oskar 1926a. Livische Märchen und Sagenvarianten. FF Communications 66. Hamina: SKS.

Loorits, Oskar 1926b. Liivi rahva usund I. Mit einem Referat: Der Volksglaube der Liven. Tartu: Tartu Ülikool.

Loorits, Oskar 1928. Liivi rahva usund II. Mit einem Referat: Der Volksglaube der Liven. Tartu: Tartu Ülikool.

Loorist, Oskar 1935. Pharaos Heer in der Volksüberlieferung. Tartu: Tartu ülikool.

Loorits, Oskar 1949. Grundzüge des estnischen Volksglaubens 1. Skrifter Utgivna av Kungl. Gustav Adolfs Akademien för Folklivsforskning 18: 1. Lund: Carl Blom.

Loorits, Oskar 1951. Grundzüge des estnischen Volksglaubens 2. Skrifter Utgivna av Kungl. Gustav Adolfs Akademien för Folklivsforskning 18: 2. Lund: Carl Blom.

Loorits, Oskar 1957. Grundzüge des estnischen Volksglaubens 3. Skrifter Utgivna av Kungl. Gustav Adolfs Akademien för Folklivsforskning 18:3. Lund: Carl Blom.

Loorits, Oskar 2000. Liivi rahva usund IV-V. Tartu: Eesti Kirjandusmuuseum.

Nagy, Ilona 1990. The Catalogue of the Hungarian Aetiological Legends. Janos Pusztay (toim) Specimina Sibirica III. Gedenkschrift für Irén N. Sebestyén (1890-1978). Quinqueecclesiae: Universitas Quinqueecclesiae, lk 149-157.

Niditch, Susan 2018. Folklore and the Hebrew Bible: Interdisciplinary Engagement and New Directions. Humanities 7 (1) (doi: 10.3390/h7010006).

PEZ 2011 = Lobach, Vladzimir. Polatski etnografichny zbornik. 2. väljalase. narodnaia proza belarusau Pazdvinnia. Navapolatsk: PDU. 
Pietkiewicz, Czeslaw 1938. Kultura duchowa Polesia Rzeczyckiego: materiaty etnograficzne. Warszawa: TNW.

Põpin, Aleksandr 1962. Pamiatniki starinnoi russkoi literatury, izdavaemye grafom Grigoriem Kushelevym-Bezborodko. Minsk: Tipografiia P. A. Kuliš.

Rogers, James 1884. Bible Folk-lore: A Study in Comparative Mythology. London: Kegan Paul, Trench.

Romanov, Evdokim 1891. Belorusskii sbornik. Skazki kosmogonicheskie i kul'turnye 4. Vitebsk: G. A. Malkin.

Seržputovski, Aleksandr 1911 = Serzhputovskii, Aleksandr. Skazki i rasskazy belorusovpoleshukov (materialy $k$ izucheniiu tvorchestva belorusov $i$ ih govora). Sankt Petersburg: Izd. russkogo iazyka i slovesnosti imperatorskoi AN.

Seržputouski, Aleksandr 1930 = Serzhputovskii, Aleksandr. Prymhi $i$ zababony belarusau-paleshukou. Minsk: Galoulitbel.

Seržputouski, Aleksandr 1998 = Serzhputovskii, Aleksandr. Prymhi $i$ zababony belarusau-paleshukou. Minsk: Universitetskae.

Shein, Pavel 1893. Materialy dlia izucheniia byta i iazyka russkogo naseleniia SeveroZapadnogo kraia 2. St. Petersburg: The Imperial Academy of Sciences.

Smirnova, Olga \& Tšuvjurov, Aleksandr 2002 = Smirnova, Olga \& Chuvjurov, Aleksandr. Khristianskie legendy v traditsionnoi kul'ture komi. Zhivaia starina 3, lk 14-16.

Sparks, Kenton L. 2005. Ancient Texts for the Study of the Hebrew Bible: A Guide to the Background Literature. Peabody, MA: Hendrickson, Baker Academic.

StTh-MIFL = Thompson, Stith 1955-1958. Motif-Index of Folk-Literature. A Classification of Narrative Elements in Folktales, Ballads, Myths, Fables, Mediaeval Romances, Exempla, Fabliaux, Jest-Books and Local Legends. Bloomington: Indiana University Press.

Šarapov, Valeri 1996 = Sharapov, Valeri. Khristianskie siuzhety v fol'klore komi staroobriadtsev Srednei Pechory. Khristianizatsiia Komi kraia $i$ ee rol' $v$ razvitii gosudarstvennosti i kul'tury 2. Syktyvkar: Komi nauchnyi centr RAN, lk 310-320.

Ziolkowski, Eric 2017. Introduction. Ziolkowski, Eric (toim). The Bible in Folklore Worldwide. A Handbook of Biblical Reception in Jewish, European Christian, and Islamic Folklores. Berlin \& Boston: de Gruyter, lk 1-42.

Zowczak, Magdalena 2013. Biblia ludowa. Interpretacje wątków biblijnych $\mathrm{w}$ kulturze ludowej. Torun: Wydawnictwo naukowe uniwersytetu Mikolaja Kopernika.

Tehillim 139 = Complete Jewish Bible. Tehillim - Psalms - Chapter 139. https://www. chabad.org/library/bible_cdo/aid/16360/jewish/Chapter-139.htm.

Tokarev, Sergei 1991. Dvupolnye suschestva. Tokarev, Sergei (toim). Mify narodov mira. Entsiklopediia I-II. Moskva: Sovetskaia entsiklopediia.

TMKB 2004 = Varfalameeva, Tamara \& Boganeva, Elena \& Kozenka, Nikolai (koost) 2004. Tradytsyinaia mastatskaia kul'tura belarusay̆ 2. Vicebskae Padzvinne. 2. Minsk: Belaruskaia Navuka. 
TMKB 2006 (2) = Boganeva, Elena 2006. Tradytsyinaia mastatskaia kul'tura belarusaỹ. 2. Grodzensk. Minsk: Vyshaia Shkola.

TMKB 2009 = Boganeva, Elena 2009. Tradytsyinaia mastatskaia kul'tura belarusay̆. 2. Brest. Minsk: Vyshaia Shkola.

TMKB 2011 = Boganeva, Elena 2011. Tradytsyinaia mastatskaia kul'tura belarusay̆. 5. Tsentral'naia Belorus. Minsk: Vyshaia Shkola.

TMKB 2013 = Boganeva, Elena 2013. Tradytsyinaia mastatskaia kul'tura belarusay̆ 6 . Gomel. Minsk: Vyshaia Shkola.

VESiL 2019 = Belova, Olga \& Gura, Aleksandr \& Kabakova, Galina \& Tolstaia, Svetlana. Vostochnoslavianskie etiologicheskie skazki i legendy. Entsiklopedicheskii slovar'. Moskva: Neolit.

Volodina, Tatjana 2018. Frazeologija i magicheskie praktiki v kontekste antropoi kosmogonicheskikh legend (belorusskaia tradicia na evropeiskom fone). Kõiva, Mare \& Volodina, Tatjana (toim). Missiia vypolnima. Perspektivy izucheniia fol'klora. Sator 19. Tartu: Nauchnoe Izdatelstvo ELM, lk 181-206 (doi: 10.7592.Sator.2018.19.07).

\title{
Summary
}

\section{The first people in the world: Belarusian and Estonian aetiologies}

\author{
Alena Boganeva \\ Head of the Department of the Ethnolinguistics and Folklore \\ Center for Belarusian Culture, Language and Literature Research \\ National Academy of Sciences, Belarus \\ elboganeva@gmail.com
}

\section{Mare Kõiva}

Leading Research Fellow

Department of Folkloristics, Estonian Literary Museum

mare.koiva@folklore.ee

Keywords: Adam, aetiology, bible-influenced folklore, Eve, parabible

Belarusian and Estonian mythological and legendary narratives, especially aetiologies, share a number of similar motifs and characters, despite the fact that Estonian and Belarusian belong to different language families and share no common borders. However, some matches in the motifs are so complete and expressive that they, we believe, cannot be explained by typology or universals. Since the topic of ties between EstonianBelarusian folklore is relatively unexplored, along with their historical contacts, the aim of this article is to point out the similarities in the motifs of Estonian and Belarusian legends regarding the first people in the context of Slavic and Finno-Ugric legends, as 
well as to represent some of the original Estonian and Belarusian aetiologies. The motives under examination are the recreation of humans, the skin of the nails, creation of a woman, the death of the first people, the motifs of the snake, eel, and weather loach, the cross of Christ, and others.

Alena Boganeva on etnolingvistika ja folkloristika osakonna juhataja Valgevene Rahvusliku Teaduste Akadeemia Valgevene Kultuuri, Keele ja Kirjanduse Uurimise Keskuses. Tema peamised uurimisvaldkonnad on piibli- ja parapiibli narratiivid, mütoloogia, rahvajutud, rahvaluule tüpoloogia ja liigiküsimused, etnokonfessionaalsete suhete etnolingvistiline aspekt. Ta on monograafiate ja arvukate artiklite autor. 2014. aastal pälvis ta Valgevene Vabariigi presidendi kultuuri, kunsti ja teaduse alase eripreemia.

Alena Boganeva is Head of the Department of the Ethnolinguistics and Folklore of the Centre for Belarusian Culture, Language and Literature Research at the National Academy of Sciences of Belarus. She explores biblical and parabiblical narratives, mythology and folk narratives, the typology of genres, ethno-confessional relations in ethno-linguistic aspect. She has authored monographs and numerous articles. In 2014 she received a special award of the President of the Republic of Belarus in the field of culture, art and science.

elboganeva@gmail.com

Mare Kõiva on Eesti Kirjandusmuuseumi folkloristika osakonna juhtivteadur ja Eesti-uuringute Tippkeskuse juht, Academia Europaea akadeemik. Ta on mitmete monograafiate ja artiklikogumike toimetaja, arvukate artiklite autor, Tema peamised välitööde alad on Bulgaaria ja Eesti. Peamised uurimisalad on usundi-uuringud, usundilised narratiivid, mütoloogia, loitsud ja targad, rituaalne aasta, etnoastronoomia ja IT humanitaarias.

Mare Kõiva is a Leading Research Fellow at the Estonian Literary Museum. She is Head of the Centre of Excellence in Estonian Studies, and member of Academia Europaea, and has edited several monographs and article collections and authored numerous articles. Her main fieldwork sites are Estonia and Bulgaria. Her main research areas cover religiosity, new religious movements, belief narratives, mythology, charms and sages, ritual year, ethnoastronomy, and IT in humanities.

mare.koiva@folklore.ee 